\title{
The Ecology of Ocypode Rotundata (Miers, 1882) in Qeshm Island Persian Gulf
}

\author{
Mojtaba Naderi ${ }^{1 *}$, Fatemeh Pishehvarzad ${ }^{2}$ and Mariano Lastra ${ }^{3}$ \\ ${ }^{1}$ Department of Agriculture, Payame Noor University (PNU), Iran \\ ${ }^{2}$ Department of Fisheries and Environmental Sciences, Tehran University, Iran \\ ${ }^{3}$ Department of Ecology and Animal Biology, University of Vigo, Spain
}

Submission: December 01, 2019; Published: January 09, 2020

Corresponding author: Mojtaba Naderi, Department of Agriculture, Payame Noor University (PNU), P.O. Box 19395-3697, Tehran, Iran

\begin{abstract}
Ghost crabs inhabit in self-constructed burrows on sandy beaches from backshore to foreshore. Ocypode rotundata is one of three species of the genus occurring in the Persian Gulf and Oman Gulf. The males of O. rotundata creates sand pyramid exactly in front of the burrow towards the seaward during the breeding season for attraction of female crabs. They play important roles in the ecology of sandy beaches of Qeshm Island. Kewords: Ocypode rotundata; Burrow; Persian Gulf; Ecology
\end{abstract}

\section{Introduction}

Ghost crabs are among the most common burrowing organisms and fastest crustaceans on sandy beach from tropics to temperate latitudes $[1,2]$. These crabs use self-constructed burrows for variation aims of needs including shelter, mating, egg development phase molting sex-specific signaling and feeding [3-10]. Moreover, ghost crabs have important effect on sediment characteristics and are the great bioturbators of sandy beaches which has important concepts for the biogeochemistry of the soil and soil biodiversity [11]. The genus Ocypode comprises 25 species which are globally distributed on tropical and subtropical [1,12-14]. Up to date, 6 species of Ocypode have previously been reported from Persian and Oman Gulfs which are, 0 . rotundata (Miers, 1882), O. sinensis (Dai, Song \& Yang, 1985), O. jousseaumei (Nobili, 1905), O. platytarsis (Milne Edwards, 1852), O. cordimanus (Latreille, 1818), O. saratan (Forskal, 1775). The first three species occur on Iranian sandy beaches whist all of five species have distributed along Oman coasts [15-18]. Moreover, distribution of 0 . rotundata occurs on 19 stations around Qeshm Island [19]. Conversely, O. sinensis has very low abundance and distribution on Qeshm Island [16].

\section{Matting}

Copulation usually occurs on the beach surface [1]. However, O. rotundata builds burrows specifically for mating which include 2 shafts: one extended straight down and another turning right or left contrariwise to the first branch (Figure 1) [20]. Male crabs use two ways for attraction of female crabs during the mating period. One of them is constructed sand mounds and another is slam of sand with both chelae (especially major chelae) [21].

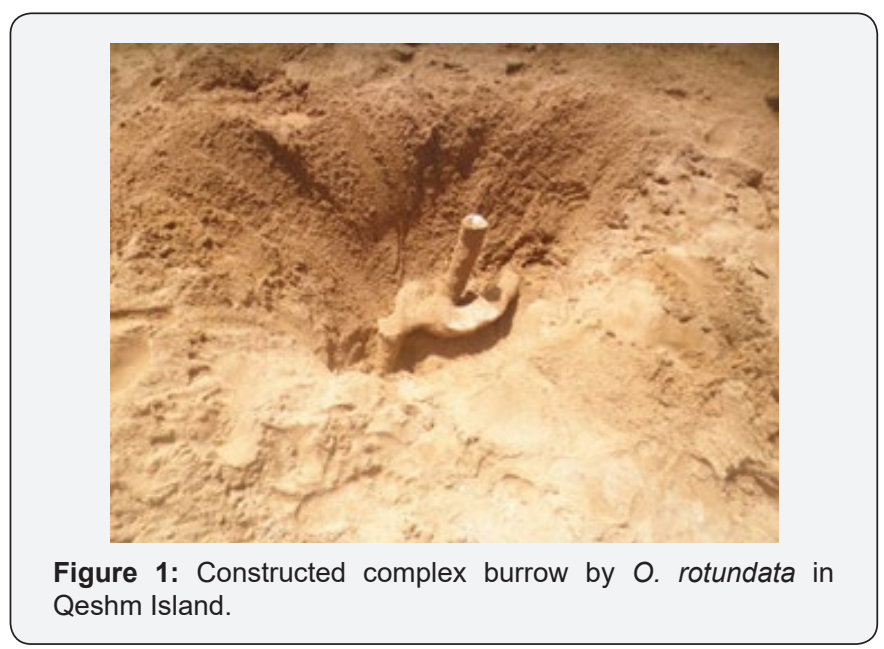

Gonad Development and Reproduction Period

Warm conditions can induce optimal gonad growth, whereas a low temperature may delay egg development and larval release $[6,7,22]$. According to Persian Gulf temperature conditions, $O$. rotundata is actively breeding from March to October [23]. 


\section{Egg Development}

The eggs of $O$. rotundata are spherical in shape which includes six developmental stages with different color patterns: yellow, pale orange, orange, dark orange, brownish, brown color [23]. The variation in color during egg development is due to differences in absorption of the yolk reserves. Like other ghost crabs $[22,24-$ 26], Ovigerous females of $O$. rotundata usually are scarce on the beach surface [23]. An admissible explanation for the low number of ovigerous female crabs could be the fact that they hide inside their deep burrows, incubating their eggs, until the appropriate time of hatching.

\section{Burrowing Behavior}

Increasing size of ghost crabs is accompanied by morphological changes (e.g. shape, diameter, length, and orientation) of burrows [1]. Juvenile crabs of 0 . rotundata construct burrow on upper foreshore due to inability of their gills to tolerate long time of air exposure. Naderi and Pishehvarzad [20] stated that 0 . rotundata individuals excavate single tube, J-shaped and Y-shaped burrows at the different growth stages, on the other hand, spiral and complex burrows only occurred in adult crabs.

\section{Feeding}

Feeding behavior of 0 . rotundata divides into three classifications: 1) deposit-feeding, 2) consuming of macroscopic plant detritus, 3) scavenging on animal carcasses (Naderi, unpublished data) (Figure 2).
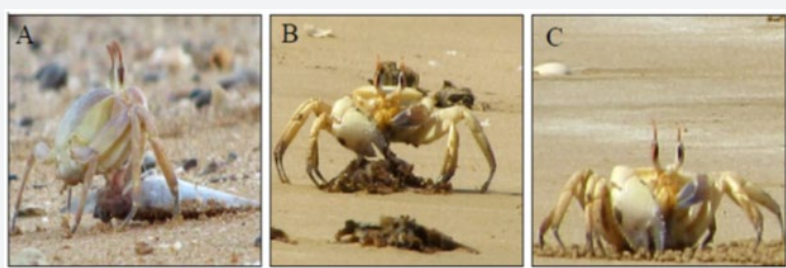

Figure 2: Feeding behavior of $O$. rotundata in Qeshm Island, $A$ deposit-feeding, B: consuming of macroscopic plant detritus, C: scavenging on animal carcasses.

\section{Food and Economic Value}

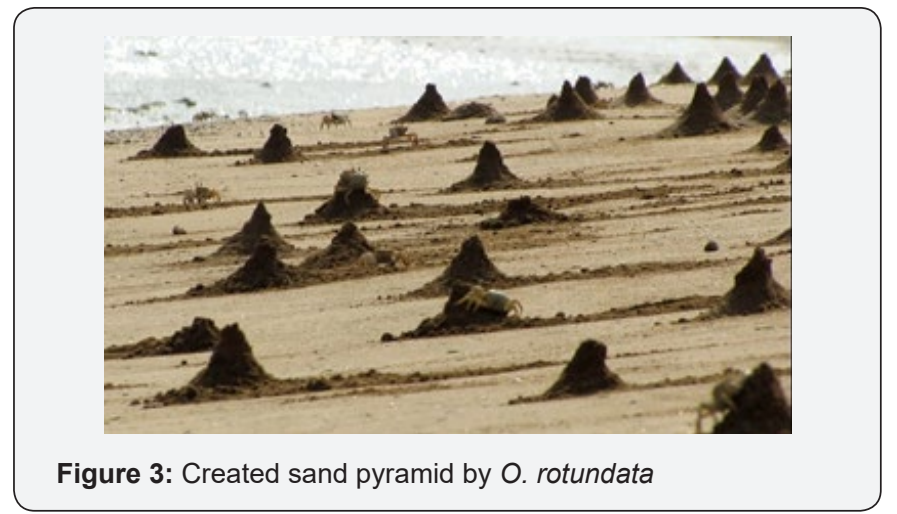

Ghost crabs are one of valuable species in Nigeria and west Africa that women catch them [27]. Also, they use as a tool for rapid assessment of human impacts on exposed sandy beaches [28]. On the other hands, tissues of 0 . rotundata include saturated fatty acids, palmitic acid, monounsaturated fatty acid, polyunsaturated fatty acids, two methyl esters of fatty acids, cholesterol which can reduce inflammation and may help to reduce risk of chronic diseases such as heart disease cancer, and arthritis [29-32]. $O$. rotundata does not use as food in Iran but it is a good choice to use as prey for fishing with hook and line (Figure 3).

\section{References}

1. Lucrezi S, Schlacher TA (2014) The ecology of ghost crab. Oceanography and Marine Biology: An Annual Review 52: 201-256.

2. Jones DA (1972) Aspects of the ecology and behaviour of Ocypode ceratophthalmus (Pallas) and O. kuhlii de Haan (Crustacea: Ocypodidae). Journal of Experimental Marine Biology and Ecology 8(1): 31-43.

3. Christoffers EW (1986) Ecology of the ghost crab Ocypode quadrata (Fabricius) on Assateague Island, Maryland and the impacts of various human uses of the beach on their distribution and abundance. Ph.D. thesis, Michigan State University, USA.

4. Kristensen E, Penha-Lopes G, Delefosse M, Valdemarsen T, Quintana CO, et al. (2012) What is bioturbation? The need for a precise definition for fauna in aquatic sciences. Marine Ecology Progress Series 446: 285302.

5. Linsenmair KE (1967) Konstruktion und Signalfunktion der sand Pyramide der Reiterkrabbe Ocypode saratan Forsk (Decapoda Brachyura Ocypodidae). Ethology: international journal of behavioural biology 24(4): 403-456.

6. Hughes DA (1973) On mating and the "copulation burrows" of crabs of the genus Ocypode (Decapoda, Brachyura). Crustaceana Journal 24: 72-79.

7. Haley SR (1972) Reproductive cycling in the ghost crab Ocypode quadrata (Fabricius) (Brachyura, Ocypodidae).Crustaceana Journal 23: 1-11.

8. Hartnoll RG (1969) Mating in the Brachyura. Crustaceana 16(2): 161181.

9. Robertson JR, Pfeiffer WJ (1982) Deposit-feeding by the ghost crab Ocypode quadrata (Fabricius). Journal of Experimental Marine Biology and Ecology 56(2-3): 165-177.

10. Trott TJ (1987) Chemoreception in the painted ghost crab Ocypode gaudichaudii H. Milne Edwards and Lucas (Brachyura: Ocypodidae): Implications for foraging. Zoologischer Anzeiger 218(5-6): 295-303.

11. Schlacher TA, Jager R, Nielsen T (2011) Vegetation and ghost crabs in coastal dunes as indicators of putative stressors from tourism. Ecological Indicators 11(2): 284-294.

12. Ng PKL, Guinot D, Davie PJF (2008) Systema Brachyurorum: Part I. An annotated checklist of extant brachyuran crabs of the world. Raffles Bulletin of Zoology 17: 1-286.

13. Shin HT, Ng PKL, Davie PJF, Schubart CD, Turkay M, et al. (2016) Systematics of the family Ocypodidae Rafinesque, 1815 (Crustacea: Brachyura), based on phylogenetic relationships, with a reorganization of subfamily rankings and a review of the taxonomic status of Uca Leach, 1814, sensulato and its subgenera. Raffles Bulletin of Zoology 64: 139-175. 
14. Wolcott TG (1978) Ecological role of ghost crabs, Ocypode quadrata (Fabricius) on an ocean beach: Scavengers or predators? Journal of Experimental Marine Biology and Ecology 31: 67-82.

15. Naderloo R, Ebrahimnezhad S, Sari AR (2015) Annotated checklist of the decapod crustaceans of the Gulf of Oman, northwestern Indian Ocean. Zootaxa 4028: 397-412.

16. Naderi M, Zare P, Lastra M, Pishehvarzad F (2018) First record of ghost crab Ocypode sinensis (Dai Song and Yang, 1985) (Decapoda: Brachyura: Ocypodidae) from Qeshm Island, Persian Gulf, Iran. Cahiers de Biologie Marine 59(6): 527-531.

17. Clayton DA (1996) Ghost crabs of Oman (Crustacea: Brachyura: Ocypodidae). Science and technology 1: 27-35.

18. McLachlan A, Fisher M, Al-Habsi HN, Al-Shukairi SS, Al-Habsi AM (1998) Ecology of sandy beaches in Oman. Journal of Coastal Conservation 4: 181-190.

19. Naderloo R, Turkay M (2012) Decapod crustaceans of the littoral and shallow sublittoral Iranian coast of the Persian Gulf: Faunistics, Biodiversity and Zoogeography. Zootaxa 3374: 1-67.

20. Naderi M, Pishehvarzad F (2019) Morphological survey of the burrows of the ghost crab Ocypode rotundata (Miers, 1882) in the southwestern Qeshm Island. Iranian Scientific Fisheries Journal 28: 1-5.

21. Schober UM, Christy JH (1993) Sand disposal of the painted ghost crab Ocypode gaudichaudii (Decapoda: Ocypodidae): a possible role in courtship. Marine Biology 116(1): 53-60.

22. Brooke ML (1981) Size as a factor influencing the ownership of copulation burrows by the ghost crab (Ocypode ceratophthalmus). Zeitschrift für Tierpsychologie 55: 63-78.

23. Naderi M, Hosseini SA, Hedayati AA, Pazooki J, Zare P, et al. (2018) Reproductive biology of Ghost crab Ocypode rotundata
(Decapoda,Ocypodidae) of Qeshm Island (Persian Gulf). Crustaceana Journal 91: 1039-1059.

24. Guillory V, Hein S (1997) Sexual maturity in blue crabs, Callinectes sapidus. Proceedings of Coastal Fishing, Louisiana's Blue Crab Resource. LA St. University Academy of Science 59: 5-7.

25. Alberto RMF, Fontoura NF (1999) Distribução e estrutura etária de Ocypode quadrata (Fabricius, 1787) (Crustacea, Decapoda, Ocypodidae) em praia arenosa do litoral sul do Brasil. Revista Brasileira de Biologia 59: 95-108.

26. Fransozo M, Negreiros-Fransozo L, Bertini G (2002) Morphometric study of the ghost crab Ocypode quadrata (Fabricius, 1887) (Brachyura, Ocypodidae) from Ubatuba, São Paulo, Brazil. Modern Approaches to the Study of Crustacea 189-195.

27. FAO (1997) women in Ogheye, fishing and fishing related activities. National agriculture research project.

28. Barros F (2001) Ghost crabs as a tool for rapid assessment of human impacts on exposed sandy beaches. Biological Conservation 97: 399404.

29. Gil A (2002) polyunsaturated fatty acids and inflammatory disease. Biomed Pharmacother 56(8): 388-396.

30. Reiffel JA, McDonald A (2006) Antiarrhythmic effects of omega-3 fatty acids. Am J Cardiol 98(4): 50-60.

31. Simon JA, Chen YH, Bent S (2009) The relation of alpha-linolenic acid to the risk of prostate cancer. Am J Clin Nutr 89(5): 1558-1564.

32. Calo L, Bianconi L, Colivicchi F (2005) N-3 fatty acids for the prevention of atrial fibrilliation after coronary artery bypass surgery. J Am Coll Cardiol 45(10):1723-1728.

This work is licensed under Creative

Commons Attribution 4.0 Licens

DOI: 10.19080/OFOAJ.2020.11.555816

\section{Your next submission with Juniper Publishers} will reach you the below assets

- Quality Editorial service

- Swift Peer Review

- Reprints availability

- E-prints Service

- Manuscript Podcast for convenient understanding

- Global attainment for your research

- Manuscript accessibility in different formats ( Pdf, E-pub, Full Text, Audio)

- Unceasing customer service

Track the below URL for one-step submission https://juniperpublishers.com/online-submission.php 